\title{
7. A List of Chromosome Numbers in Angiospermous Plants VII.
}

\author{
By Toranosuke SugruRA. \\ Botanical Institute, Osaka Higher School. \\ (Comm. by S. IKeno, M.I.A., Jan. 13, 1941.)
}

In the following list the meiotic numbers of chromosomes in 43 plants, belonging to 8 families recently studied, are enumerated.

In Phyteuma we know various numbers of meiotic chromosomes which conferm the fact that it consists of several groups. There seems to be two groups in the sec. Hedranthum: one the $n=18$ group and the other the $\mathrm{n}=13$ group to which $P$. nigrum and $P$. Halleri belong.

And the $n=12$ and $n=17$ groups are found in the sec. Podanthum, although systematists have not been concerned with these.

Phyteuma lobelioides belongs to the former group and $P$. campanuloides to the latter. More comprehensive karyological descriptions with illustrations will be published later.

The plants used were all raised from seeds which were kindly supplied by the chief botanical gardens in Europe, to the authorities of which the writer wishes to express his best thanks.

The division of the pollen mother cells in all plants here listed was carried out by the furrowing method*.

\begin{tabular}{|c|c|c|c|c|c|}
\hline Plants inv & vestigated & $\begin{array}{c}\text { Chromo- } \\
\text { some } \\
\text { number }\end{array}$ & Plants in & vestigated & $\begin{array}{c}\text { Chromo- } \\
\text { some } \\
\text { number }\end{array}$ \\
\hline Campanulaceae & & & $P$. & Halleri & 13 \\
\hline Adenophora & liliifolia & 51 & $P$. & nigrum & 13 \\
\hline Campanula & caespitosa & 34 & Prismatocarp & us strictus & 17 \\
\hline$C$ & calaminthifolia & 17 & Symphyandra & Hoffmannii & 17 \\
\hline C. & celtidifolia & 17 & & & \\
\hline$C$. & cervaria & 15 & Gesneriaceae & & \\
\hline C. & Hostii & 34 & Streptocarpus & grandis & 16 \\
\hline$C$. & laciniata & 51 & $S$ & Haygarthii & 16 \\
\hline C. & lanata & 17 & & & \\
\hline$C$. & multifoliata & 17 & Lamiaceae & & \\
\hline$C$. & Poscharskyana & 17 & Nepeta & stachyoides & 9 \\
\hline C. & psilostachya & 17 & Salvia & ethiopica & 8 \\
\hline$C$. & sarmentosa & 17 & & & \\
\hline$C$. & subpyrenaica & 8 & Plumbaginaceae & & \\
\hline C. & tomentosa & 17 & Statice & Thouinii & 8 \\
\hline Hedraeanthus & graminifolius & 16 & $S$ & superba & 8 \\
\hline$H$ & tenuifolius & 16 & Armeria & arctica & 9 \\
\hline Isotoma & longiflora & 14 & A. & baetica & 9 \\
\hline Phyteuma & campanuloides & 17 & A. & berlengensis & 9 \\
\hline$P$ & lobelioides & 12 & A. & cariensis & 9 \\
\hline
\end{tabular}

* Sugiura, T. 1936 b. Studies on the Chromosome Numbers in Higher Plants, with Special Reference to Cytokinesis, I. Cytologia, 7. 


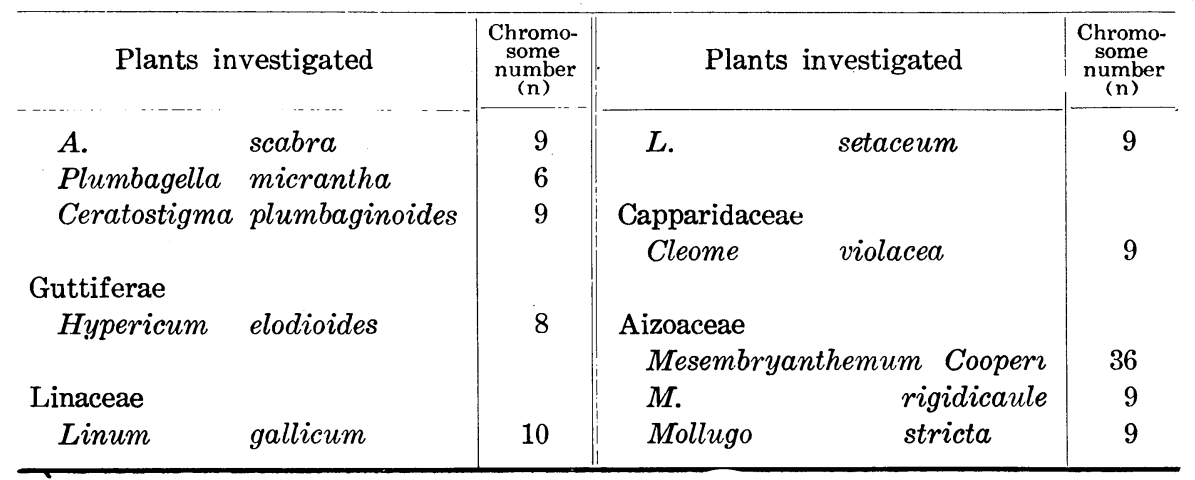

